Acta Crystallographica Section B

Structural

Science

ISSN 0108-7681
Marcia Rusjan, ${ }^{\text {a,b }}$ Zulema Chaia, ${ }^{a}$ Oscar E. Piro, ${ }^{c}$ Daniel Guillon ${ }^{d}$ and Fabio D. Cukiernik ${ }^{a, b *}$

\footnotetext{
a INQUIMAE, Departamento de Química Inorgánica, Analítica y Química Física, Facultad de Ciencias Exactas y Naturales, Universidad de Buenos Aires, Pabellón II, Ciudad Universitaria, 1428 Buenos Aires, Argentina, $\mathbf{b}_{\text {Instituto de }}$ Ciencias, Universidad Nacional de General Sarmiento, Roca 850, 1663 San Miguel, Buenos Aires, Argentina, 'cDepartamento de Física, Facultad de Ciencias Exactas, Universidad Nacional de La Plata and IFLP (CONICET), CC 67, 1900 La Plata, Argentina, and Institut de Physique et Chimie des Matériaux de Strasbourg, Groupe des Matériaux Organiques, 23 rue du Loess, 67037 Strasbourg CEDEX, France
}

Correspondence e-mail:

fabioc@cuca.q1.fcen.uba.ar

\section{Synthesis, structure and magnetic properties of tetrakis- $\mu$-carboxylato-bis(dodecylnicotinato)dicop- per(II) complexes; crystal and molecular structure of the decyl carboxylate derivative}

Dodecylnicotinate bis-adducts of binuclear copper carboxylates, of the general formula $\mathrm{Cu}_{2}\left(\mathrm{O}_{2} \mathrm{CC}_{n-1} \mathrm{H}_{2 n-1}\right)_{4}\left(\mathrm{C}_{5} \mathrm{H}_{4} \mathrm{~N}\right.$ $\left.\mathrm{COOC}_{12} \mathrm{H}_{25}\right)_{2}$, were synthesized for $n=10,12,14,16,18$ and 20 , and their crystal structure, thermal behavior and magnetic properties studied. The molecular structure of the decyl derivative has been determined from single-crystal X-ray diffraction data. The dimer is centrosymmetric with the $\mathrm{Cu}^{\mathrm{II}}$ ions in a square-pyramidal coordination with four $\mathrm{O}$-alkyl $\mathrm{O}$ atoms [average $d(\mathrm{Cu}-\mathrm{O}) 1.960$ (6) $\AA$ ] in the basal plane and the nicotine $\mathrm{N}$ atom at apical positions $[d(\mathrm{Cu}-\mathrm{N})$

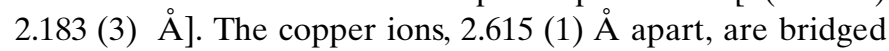
by four O-alkyl carboxylate groups. Both the $n=20$ and $n=$ 18 homologues exhibit lamellar phases, which can be related to the supramolecular arrangement found in the $n=10$ derivative. The magnetic behavior of the decyl and octadecyl dimers was studied in the $2-300 \mathrm{~K}$ temperature range. They exhibit a strong intramolecular antiferromagnetic interaction $\left(\mathrm{Cu}-\mathrm{Cu}\right.$ superexchange coupling constant $J=-347 \mathrm{~cm}^{-1}$ for the decyl derivative), which can be attributed to a large overlap of the metal $3 d$ orbitals and the oxygen lone pair orbitals of the linking carboxylate groups.

\section{Introduction}

Investigations on dicopper carboxylates exhibiting the lantern structure have been directed for a variety of interests (Mehrotra \& Bohra, 1983; Kato \& Muto, 1988). The structural and magnetic properties of the acetate derivative in the past were considered to be very important in the understanding of magnetic exchange in dinuclear compounds, relevant topics in inorganic and physical chemistry, and in the development of appropriate models to describe the magnetic coupling between metal centers (Bleaney \& Bowers, 1952; Kahn, 1993).

More recent studies on long-chain derivatives showed their potential application as advanced materials, as they exhibit thermotropic columnar mesophases (Abied et al., 1987; IbnElhaj et al., 1992; Marchon et al., 1992), and also as biologically active substances and antifungal agents, for which bis(nicotinamide derivatives) adducts are examples (Mehrotra \& Bohra, 1983; Kozlevcar et al., 1996).

All the copper carboxylate liquid crystals reported thus far are polymeric, the axial position of each $\mathrm{Cu}^{2+}$ ion being occupied, in the $\mathrm{Cu}_{2}\left(\mathrm{O}_{2} \mathrm{CR}\right)_{4}$ series, by an $\mathrm{O}$ atom of a neighbor dimer. To break this polymeric structure into distinct dimers we decided to 'block' the axial positions of the longchain dicopper carboxylates by forming bis(pyridine derivative) adducts (like in the nicotinamide antifungals). As in the equatorial carboxylate, the axial ligand we used also bears a long chain.
Received 8 November 1999

Accepted 4 February 2000 
We report here the synthesis, spectroscopic and structural characterization, phase transitions and magnetic properties of tetrakis- $\mu$-carboxylato-bis(dodecylnicotinato)-dicopper(II) complexes $\mathrm{Cu}_{2}\left(\mathrm{O}_{2} \mathrm{CC}_{n-1} \mathrm{H}_{2 n-1}\right)_{4}\left(\mathrm{C}_{5} \mathrm{H}_{4} \mathrm{NCOOC}_{12} \mathrm{H}_{25}\right)_{2}$ for $n=10,12,14,16,18$ and 20 , including the crystal and molecular structure of the decyl derivative.

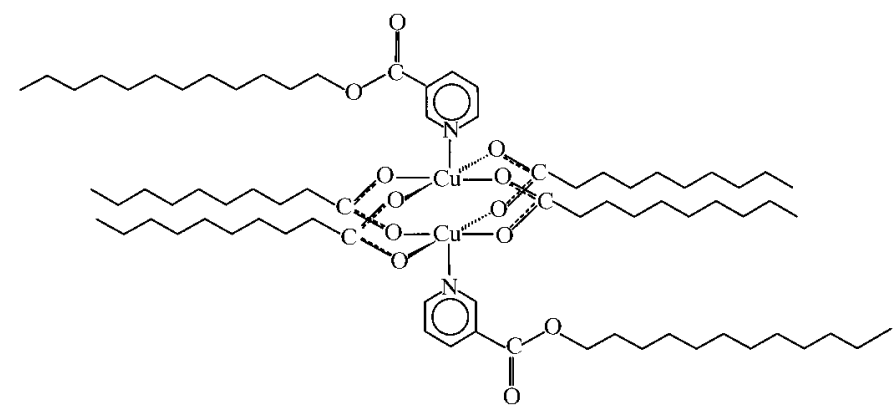

\section{Experimental}

\subsection{Synthesis of dodecyl nicotinate $\left(\mathrm{C}_{5} \mathrm{H}_{4} \mathrm{NCOOC}_{12} \mathrm{H}_{25}\right)$}

Nicotinic acid (2.53 g, $20.5 \mathrm{mmol})$ was refluxed with a large excess of $\mathrm{SOCl}_{2}$ for $4 \mathrm{~h}$ under an $\mathrm{N}_{2}$ atmosphere in an anhydrous toluene and DMF (10:1) mixture. Excess thionyl chloride was removed after reaction by vacuum distillation. Dodecanol (14 ml, $62 \mathrm{mmol})$ dissolved in toluene was added to the nicotinyl chloride and the mixture was stirred for $4 \mathrm{~h}$ at $353 \mathrm{~K}$ under an $\mathrm{N}_{2}$ atmosphere. The reaction mixture was then poured into water and $\mathrm{NaOH} 10 \%$ was added to alkalinity. The product was extracted with diethyl ether, the organic fraction washed with water and the solvents removed in vacuum. The oily product was purified by silica gel chromatography in cyclohexane: diethyl ether gradient. Yield: $83 \%$. ${ }^{1} \mathrm{H}$ NMR: $\delta 9.23(\mathrm{~d}, 1 \mathrm{H}$, pyridine ring), $8.77(\mathrm{dd}, 1 \mathrm{H}$, pyridine ring), $8.29(\mathrm{~m}, 1 \mathrm{H}$, pyridine ring $), 7.39(\mathrm{~m}, 1 \mathrm{H}$, pyridine ring $)$, $4.35\left(\mathrm{t}, 2 \mathrm{H}, \mathrm{CH}_{2}\right), 1.78\left(\mathrm{q}, 2 \mathrm{H}, \mathrm{CH}_{2}\right), 1.26\left(\mathrm{~m}, 18 \mathrm{H}, \mathrm{CH}_{2}\right), 0.88$ $\left(\mathrm{t}, 3 \mathrm{H}, \mathrm{CH}_{3}\right)$.

\subsection{Synthesis of $\mathrm{Cu}_{2}\left(\mathrm{O}_{2} \mathrm{CC}_{n-1} \mathrm{H}_{2 n-1}\right)_{4}\left(\mathrm{C}_{5} \mathrm{H}_{4} \mathrm{NCOO}\right.$ - $\left.\mathrm{C}_{12} \mathrm{H}_{25}\right)_{2}$ compounds}

Dodecyl nicotinate $(2 \mathrm{mmol})$ was dissolved in $10 \mathrm{ml}$ of boiling $n$-heptane. The corresponding copper carboxylate ( $0.5 \mathrm{mmol}$ in $10 \mathrm{ml}$ of boiling $n$-heptane), synthesized as described by Ibn-Elhaj et al. (1992), was added dropwise. The mixture was refluxed for $30 \mathrm{~min}$ and then cooled to $255 \mathrm{~K}$ overnight. A green solid was recovered by filtration at low temperature. The solid was dried in vacuum over silica. The compound with $\mathrm{n}=10$ crystallized as green platelet crystals, from which single-crystal samples were selected for crystallographic studies.

Anal.: exp. (calc.) for $n=10$ : C 65.57 (65.43), N 2.08 (2.01), H 9.39 (9.68), yield 49\%; for $n=12$ : C 66.65 (66.94), N 1.85 (1.85), H 9.91 (10.03), yield 54\%; for $n=14$ : C 67.99 (68.23), N 1.79 (1.73), H 9.19 (10.33), yield 84\%; for $n=16$ : C 69.59 (69.36), N 1.61 (1.61), H 10.68 (10.59), yield $91 \%$; for $n=18$ : C
69.59 (70.35), N 1.49 (1.51), H 10.76 (10.82), yield 70\%; for $n=$ 20: C 71.12 (71.23), N 1.49 (1.43), H 10.94 (11.03), yield 75\%.

\subsection{Physicochemical methods}

IR spectroscopy was carried out on a Nicolet FTIR 510P with $\mathrm{KBr}$ pellets and UV-vis measurements on a HP8453 spectrometer. ${ }^{1} \mathrm{H}$ NMR spectra were run on a Bruker AC200 in $\mathrm{CDCl}_{3}$. Differential scanning calorimetry (DSC) was performed on a Shimadzu DSC-50 calorimeter. For optical microscopy observations, a Leitz DMRX microscope equipped with a Leitz 1350 heating stage device was used. Elemental analyses were performed on a Carlo Erba CHNS-O EA1108 instrument.

Magnetic measurements between $2 \mathrm{~K}$ and room temperature were performed on a Quantum Design MPMS-XL susceptometer in a $5000 \mathrm{G}$ magnetic field. The powdered samples, typically 5-15 mg, were placed in a cellophane bag. Raw magnetic data were corrected for the sample holder contribution and for the sample diamagnetism, which was evaluated using Pascal's constants (Selwood, 1956).

Variable-temperature powder X-ray diffraction (XRD) patterns were recorded using an INEL CPS-120 curved position-sensitive detector and $\mathrm{Cu} K \alpha$ radiation from an INEL $\mathrm{X}$-ray generator; room-temperature data were collected on Siemens D5000 equipment.

\subsection{Single-crystal diffraction data and structure solution and refinement of $\mathrm{Cu}_{2}\left(\mathrm{O}_{2} \mathrm{CC}_{9} \mathrm{H}_{19}\right)_{4}\left(\mathrm{C}_{5} \mathrm{H}_{4} \mathrm{NCOOC}_{12} \mathrm{H}_{25}\right)_{2}$}

Crystal data, data collection procedure, structure determination methods and refinement results are summarized in Table 1. ${ }^{\mathbf{1}}$ As expected for a complex with extended organic ligands, the samples turned out to diffract poorly. Only about $59 \%$ of the X-ray intensity data up to 0.841 A resolution were above two standard deviations of measurement errors.

Several $\mathrm{H}$ atoms were detected at approximate locations in a difference Fourier map. They, however, were positioned stereochemically and refined with the riding model. During the refinement, the $\mathrm{CH}_{3} \mathrm{H}$ atoms were allowed to rotate as a rigid group around the $\mathrm{C}-\mathrm{CH}_{3}$ bond so as to maximize the sum of the electron density at the three calculated hydrogen positions.

\section{Results and discussion}

\subsection{Synthesis and characterization}

The formation of the expected complexes was first studied in solution. Experiments carried out with $\mathrm{Cu}_{2}\left(\mathrm{O}_{2} \mathrm{CC}_{9} \mathrm{H}_{19}\right)_{4}$ dissolved in toluene showed a progressive conversion of the $678 \mathrm{~nm}$ absorption band of the starting complex into a new band centered at $c a 702 \mathrm{~nm}$, as the dodecyl nicotinate

\footnotetext{
${ }^{1}$ Supplementary data for this paper, including listings of atomic anisotropic displacement parameters, full bond distances and angles, H-atom positions calculated and observed structure factor amplitudes for the $n=10$ compound are available from the IUCr electronic archives (Reference: CA0004). Services for accessing these data are described at the back of the journal. Powder XRD patterns for $n=12,14,16,18$ and 20 derivatives are available from the authors.
} 
Table 1

Experimental details.

\begin{tabular}{|c|c|}
\hline \multicolumn{2}{|l|}{ Crystal data } \\
\hline Chemical formula & {$\left[\mathrm{Cu}\left(\mathrm{C}_{10} \mathrm{H}_{19} \mathrm{O}_{2}\right)_{4}\left(\mathrm{C}_{18} \mathrm{H}_{29} \mathrm{NO}_{2}\right)_{2}\right]$} \\
\hline Chemical formula weight & 1394.93 \\
\hline Cell setting & Triclinic \\
\hline Space group & $P \overline{1}$ \\
\hline$a(\AA)$ & $10.231(3)$ \\
\hline$b(\AA)$ & $12.878(4)$ \\
\hline$c(\AA)$ & $16.804(2)$ \\
\hline$\alpha\left(^{\circ}\right)$ & $92.39(2)$ \\
\hline$\beta\left(^{\circ}\right)$ & $104.31(2)$ \\
\hline$\gamma\left({ }^{\circ}\right)$ & $106.17(3)$ \\
\hline$V\left(\AA^{3}\right)$ & $2045.8(9)$ \\
\hline$Z$ & 1 \\
\hline$D_{x}\left(\mathrm{Mg} \mathrm{m}^{-3}\right)$ & 1.132 \\
\hline$D_{m}\left(\mathrm{Mg} \mathrm{m}^{-3}\right)$ & 1.12 \\
\hline Density measured by & Immersion \\
\hline Radiation type & Mo $K \alpha$ \\
\hline Wavelength $(\AA ̊)$ & 0.71073 \\
\hline$F(000)$ & 758 \\
\hline $\begin{array}{l}\text { No. of reflections for cell } \\
\text { parameters }\end{array}$ & 23 \\
\hline$\theta$ range $\left({ }^{\circ}\right)$ & $9.8-15.71$ \\
\hline$\mu\left(\mathrm{mm}^{-1}\right)$ & 0.574 \\
\hline Temperature (K) & $293(2)$ \\
\hline Crystal form & Plate \\
\hline Crystal size $(\mathrm{mm})$ & $0.44 \times 0.40 \times 0.16$ \\
\hline Crystal colour & Blue-green \\
\hline \multicolumn{2}{|l|}{ Data collection } \\
\hline Diffractometer & Enraf-Nonius CAD-4 \\
\hline Data collection method & $\omega-2 \theta$ scans \\
\hline Absorption correction & $\begin{array}{l}\text { Numerical (Busing \& Levy, } \\
\text { 1957) }\end{array}$ \\
\hline$T_{\min }$ & 0.793 \\
\hline$T_{\max }$ & 0.916 \\
\hline No. of measured reflections & 7627 \\
\hline No. of independent reflections & 6369 \\
\hline No. of observed reflections & 4529 \\
\hline Criterion for observed reflections & $I>2 \sigma(I)$ \\
\hline$R_{\text {int }}$ & 0.036 \\
\hline$\theta_{\max }\left({ }^{\circ}\right)$ & 24.97 \\
\hline Range of $h, k, l$ & $-12 \rightarrow h \rightarrow 11$ \\
\hline & $-15 \rightarrow k \rightarrow 15$ \\
\hline & $0 \rightarrow l \rightarrow 19$ \\
\hline No. of standard reflections & 1 \\
\hline Frequency of standard reflections & Every $30 \mathrm{~min}$ \\
\hline Intensity decay $(\%)$ & 1.5 \\
\hline \multicolumn{2}{|l|}{ Refinement } \\
\hline Refinement on & $F^{2}$ \\
\hline$R\left[F^{2}>2 \sigma\left(F^{2}\right)\right]$ & 0.0504 \\
\hline$w R\left(F^{2}\right)$ & 0.1295 \\
\hline$S$ & 1.086 \\
\hline $\begin{array}{l}\text { No. of reflections used in } \\
\text { refinement }\end{array}$ & 6369 \\
\hline No. of parameters used & 423 \\
\hline $\mathrm{H}$-atom treatment & H-atom parameters constrained \\
\hline Weighting scheme & $\begin{aligned} w & =1 /\left[\sigma^{2}\left(F_{o}^{2}\right)+(0.0878 P)^{2}\right. \\
& +0.2591 P] \\
& \text { where } P=\left(F_{o}^{2}+2 F_{c}^{2}\right) / 3\end{aligned}$ \\
\hline$(\Delta / \sigma)_{\max }$ & -0.006 \\
\hline$\Delta \rho_{\max }\left(\mathrm{e} \AA^{-3}\right)$ & 0.393 \\
\hline$\Delta \rho_{\min }\left(\mathrm{e} \AA^{-3}\right)$ & -0.288 \\
\hline Extinction method & None \\
\hline $\begin{array}{l}\text { Source of atomic scattering } \\
\text { factors }\end{array}$ & $\begin{array}{l}\text { International Tables for } \\
\text { Crystallography (1992, Vol. C, } \\
\text { Tables 4.2.6.8 and 6.1.1.4) }\end{array}$ \\
\hline
\end{tabular}

Computer programs

Data collection

Cell refinement

Data reduction
Table 1 (continued)
Structure solution

Structure refinement

Preparation of material for publication
SHELXS86 (Sheldrick, 1990)

SHELXL93 (Sheldrick, 1993)

SHELXL93 (Sheldrick, 1993) concentration increased. This shift is consistent with a change in the coordination number around $\mathrm{Cu}^{2+}$ from four to five. For example, the pyridine adduct band shifts down in energy to $713 \mathrm{~nm}$ owing to its strong interaction with copper. Job's method (Reilley \& Sawyer, 1961) clearly indicated a 1:2 complex-to-nicotinate ligand ratio, as expected for a bisadduct, but also showed that the stability constant for this $\mathrm{Cu}_{2}\left(\mathrm{O}_{2} \mathrm{CR}\right)_{4}$ (nicotinate) $)_{2}$ compound is not very high. To overcome this we performed the synthesis of the compounds in excess dodecyl nicotinate ligand; their high solubility in non-polar solvents indicated that a low-temperature crystallization process was necessary.

The characterization of the solid product was completed by the crystal structure determination of the decyl derivative by XRD methods (see below) and IR spectroscopy. The main IR bands are, in addition to the $v_{\mathrm{CH}_{3}}, v_{\mathrm{CH}_{2}}$ stretching vibrations characteristic of long-chain organic compounds, the $v_{\mathrm{CO}_{2}}$ vibration of the ester at $1725-1740 \mathrm{~cm}^{-1}$, the $v_{\text {py }}$ symmetric stretching mode of the pyridine ring $\left(1591 \mathrm{~cm}^{-1}\right.$ in the free ligand) shifted by coordination to $1616-1618 \mathrm{~cm}^{-1}$, as well as the $v_{\mathrm{CO}_{2}}$ symmetric and asymmetric stretching modes of the bridging carboxylates at $1424-1437 \mathrm{~cm}^{-1}$ (depending on the carboxylate chain length) and 1599-1588 $\mathrm{cm}^{-1}$, respectively. These values agree with those found for bis-nicotinamide copper carboxylates (Kozlevcar et al., 1996).

\subsection{Crystallographic structural results and discussion for the $n=10$ derivative}

Atomic fractional coordinates and equivalent isotropic displacement parameters are given in Table 2. Selected bond distances and angles are listed in Table 3. Fig. 1 is an ORTEP (Johnson, 1965) drawing of the dimeric complex.

The $\mathrm{Cu}_{2}\left(\mathrm{O}_{2} \mathrm{C}\left(\mathrm{CH}_{2}\right)_{8} \mathrm{CH}_{3}\right)_{4}\left(\mathrm{C}_{5} \mathrm{H}_{4} \mathrm{NCO}_{2}\left(\mathrm{CH}_{2}\right)_{11} \mathrm{CH}_{3}\right)_{2}$ complex is located on a crystallographic inversion center. The pair of $\mathrm{Cu}^{\mathrm{II}}$ ions in a dimer are bridged through the carboxylate groups of four $\mathrm{CH}_{3}\left(\mathrm{CH}_{2}\right)_{8} \mathrm{CO}_{2}{ }^{-}$ligands. Each $\mathrm{Cu}$ atom is in an elongated octahedral environment, coordinated equatorially to four carboxylate $\mathrm{O}$ atoms of two independent $\mathrm{CH}_{3}\left(\mathrm{CH}_{2}\right)_{8} \mathrm{CO}_{2}{ }^{-}$moieties $[\mathrm{Cu}-\mathrm{O}$ bond distances vary from 1.950 (3) to $1.966(2) \AA]$ and axially by the pyridine nitrogen of a $\mathrm{C}_{5} \mathrm{H}_{4} \mathrm{NCO}_{2}\left(\mathrm{CH}_{2}\right)_{11} \mathrm{CH}_{3}$ molecule $[d(\mathrm{Cu}-\mathrm{N})=$ 2.183 (3) $\AA$ ] and by the other inversion-related $\mathrm{Cu}$ atom located at 2.615 (1) $\AA$. The local molecular symmetry is close to $D_{4 h}$. The nicotinate ring plane is approximately coplanar to one of the $\mathrm{C}-\mathrm{O}-\mathrm{Cu}-\mathrm{O}-\mathrm{C}$ bonds, but slightly bent by $11^{\circ}$ with respect to the $\mathrm{Cu}-\mathrm{Cu}$ direction. 
The $\mathrm{Cu}-\mathrm{Cu}$ distance is the second shortest $\mathrm{Cu}-\mathrm{Cu}$ distance found for $\mathrm{Cu}_{2}\left(\mathrm{O}_{2} \mathrm{C}_{n} \mathrm{H}_{2 n-1}\right)_{4} L_{2}$ compounds. This can be related to the moderate basicity of the axial pyridinic ligand (Melník et al., 1985; Melník, 1982); in fact, the only compound which exhibits a shorter $\mathrm{Cu}-\mathrm{Cu}$ distance is the pyrazine derivative, the least basic axial ligand $\left(\mathrm{p} K_{a}=0.65\right)$ for which the bis-adduct has been structurally characterized. The $\mathrm{Cu}-\mathrm{O}$ distances are also slightly shorter than the corresponding values reported previously in the range 1.96-1.98 $\AA$ (Melník et al., 1985). The observed $\mathrm{Cu}-\mathrm{O}_{\mathrm{eq}} / \mathrm{Cu}-\mathrm{N}_{\mathrm{ax}}$ distances relationship is as expected on the basis of the local electroneutrality principle (Kato \& Muto, 1988; Pauling, 1960) for such a weak basic ligand.

One of the two independent alkyl chains of the equatorial carboxylates is completely elongated, in a fully extended zigzag trans arrangement, whereas the other aligns parallel to the first one after a gauche conformation at the $\mathrm{C}(12)-\mathrm{C}(13)$ bond. The alkyl chain of the nicotinate ligand is also in an extended conformation, after turning at the $\mathrm{C}(37)$ atom, rotated from the nicotinate plane to align with the carboxylate chains (see Fig. 1). Both the equatorial ligands and the nicotinate alkyl chain are straight and tilt slightly with respect to the plane perpendicular to the $\mathrm{N}-\mathrm{Cu}-\mathrm{Cu}-\mathrm{N}$ axis. Three crystallographycally non-equivalent alkyl chains converge in a plane: that belonging to the elongated carboxylate is positioned between the alkyl chain of the other non-equivalent carboxylate from the same dimer and a third one belonging to a nicotinate of a neighboring molecule. These alkyl chains are completely interdigitated (see Fig. 2), leading to the formation of two different layers along the crystal: one is defined by the polar copper carboxylate cores and the second, non-polar one contains the alkyl chains. This type of polar-nonpolar layer arrangement is typically found in mesomorphic systems.

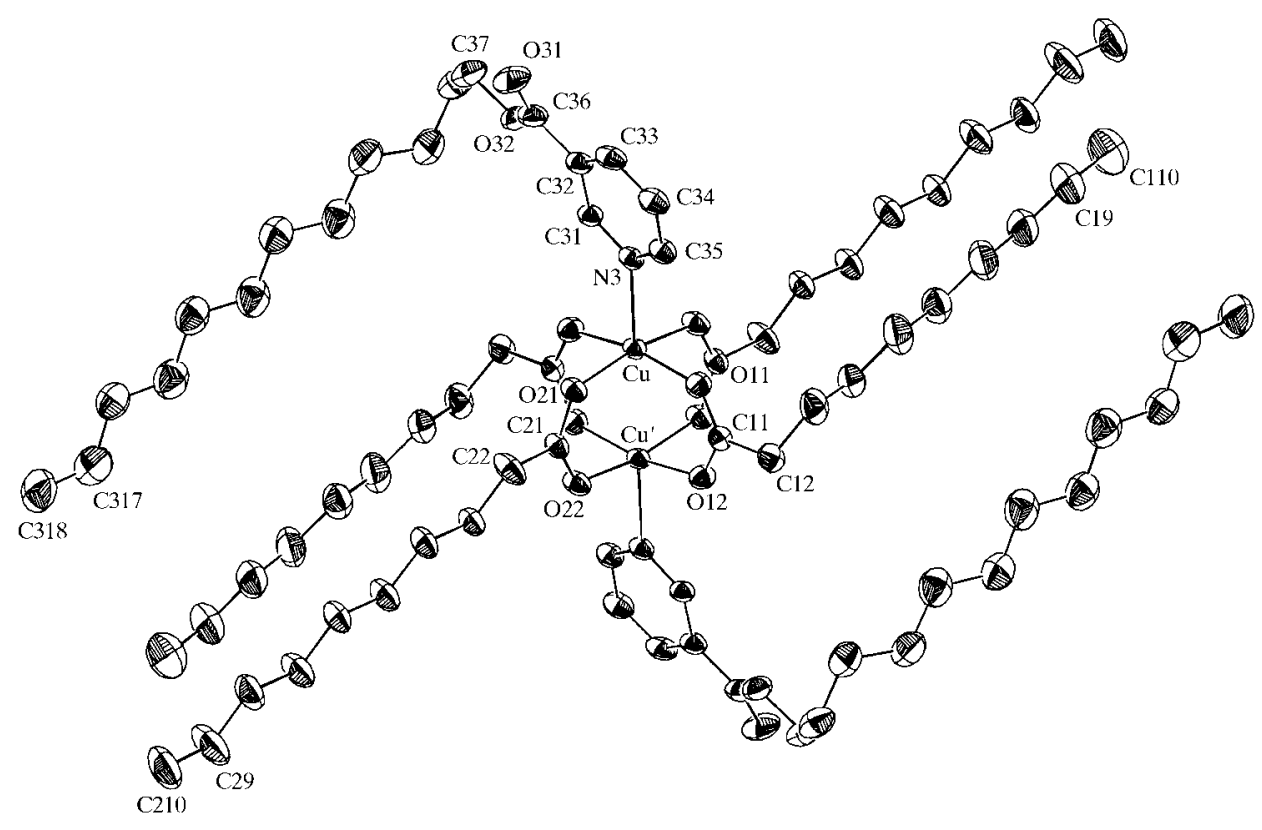

Figure 1

ORTEP (Johnson, 1965) drawing of $\mathrm{Cu}_{2}\left(\mathrm{O}_{2} \mathrm{CC}_{9} \mathrm{H}_{19}\right)_{4}\left(\mathrm{C}_{5} \mathrm{H}_{4} \mathrm{NCOOC}_{12} \mathrm{H}_{25}\right)_{2}$ showing the numbering scheme of the non-H atoms.

\subsection{Phase transitions and thermal behavior of the $\mathrm{Cu}_{2}\left(\mathrm{O}_{2} \mathrm{CC}_{n-1} \mathrm{H}_{2 n-1}\right)_{4}\left(\mathrm{C}_{5} \mathrm{H}_{4} \mathrm{NCO}_{2} \mathrm{C}_{12} \mathrm{H}_{25}\right)_{2}$ series}

The compound in which $n=20$ exhibits a lamellar phase from room temperature up to $377 \mathrm{~K}$, where it melts to the isotropic liquid. The interlamellar distance, $d_{100}$, is $49.4 \AA$ at $298 \mathrm{~K}$, but it sharply changes to $49.1 \AA$ at $325 \mathrm{~K}$ and then to $52.8 \AA$ at $339 \mathrm{~K}$. This contraction-expansion sequence correlates with phase transitions detected in DSC measurements. Table 4 contains the thermodynamic parameters of these transitions. The experimental interlamellar distance is in good agreement with the molecular length in an elongated conformation, estimated as $52 \AA$ by extrapolation from the solved structure for the $n=10$ derivative. The $n=18$ homologue showed a transition to a lamellar phase at $333 \mathrm{~K}\left(d_{100}=46.7 \AA\right.$, consistent with an estimated length of $47 \AA$ ). During the phase transitions of both compounds some differences in the high diffraction angle region have been observed, revealing changes in the crystalline order at the aliphatic chain packing level. The powder XRD patterns of the $n=12,14$ and 16 derivatives are much more complicated, precluding any straightforward assignment. As mentioned above, the crystal structure of the decyl derivative can also be interpreted as a layered arrangement of polar cores on the $a b$ plane separated by aliphatic chains, but now the interlamellar separation is about half that expected for a segregated bilayer. This is due to the intercalation of the alkyl chains belonging to neighboring dimers related to each other by a unit cell translation along the $c$ axis.

Interestingly, the differences in the supramolecular features between long-chain and short-chain derivatives can be correlated with molecular characteristics. Indeed, the IR spectra showed that the position of the $v_{\mathrm{CO}_{2}}$ symmetric stretching band depends on the chain length: it appears at $1599 \mathrm{~cm}^{-1}$ for the $n=10,12,14$ and 16 compounds, and at $1588 \mathrm{~cm}^{-1}$ for the $n=18$ and 20 derivatives. The difference between the $v_{\mathrm{CO}_{2}}$ asymmetric and symmetric stretching mode wavenumbers decreases from $176 \mathrm{~cm}^{-1}$ for $n=10$ to $150 \mathrm{~cm}^{-1}$ for $n=20$, thus reflecting a more symmetric coordination (Deacon \& Phillips, 1980) of the equatorial ligands as the chain length increases.

No liquid crystal phases have been found for these compounds, despite the presence of the long alkyl chains and the rich polymorphism they exhibited before melting to the isotropic liquid. All the studied compounds decompose between 493 and $513 \mathrm{~K}$. The thermal stability is higher than those of nicotinamide adducts of 
copper carboxylates (Kozlevcar et al., 1996).

\subsection{Magnetic behavior}

Fig. 3 shows the molar magnetic susceptibility $(\chi)$ of the $\mathrm{Cu}_{2}\left(\mathrm{O}_{2} \mathrm{CC}_{9} \mathrm{H}_{19}\right)_{4}\left(\mathrm{C}_{5} \mathrm{H}_{4} \mathrm{NCOOC}_{12} \mathrm{H}_{25}\right)_{2}$ dimer measured as a function of temperature. As for the other lantern-structured copper carboxylates, these data correspond to a system with two antiferromagnetically coupled $S=\frac{1}{2}$ centers (the increase of $\chi$ at low temperature is due to a very small amount of a paramagnetic impurity, very likely being a monomeric $\mathrm{Cu}^{2+}$ species). The octadecyl derivative, $\mathrm{Cu}_{2}\left(\mathrm{O}_{2} \mathrm{CC}_{17} \mathrm{H}_{35}\right)_{4}\left(\mathrm{C}_{5} \mathrm{H}_{4} \mathrm{~N}\right.$ $\left.\mathrm{COOC}_{12} \mathrm{H}_{25}\right)_{2}$, exhibits essentially the same $\chi$ versus $T$ variation.

The magnetic behavior of the copper unpaired electrons $\left(S_{1}=S_{2}=1 / 2\right)$ in the dimeric complex can be described by the following Hamiltonian (Bleaney \& Bowers, 1952)

$$
\begin{aligned}
H= & \left(V_{1}+V_{2}\right)-J \mathbf{S}_{1} . \mathbf{S}_{2}+\gamma\left(\mathbf{L}_{1} \cdot \mathbf{S}_{1}+\mathbf{L}_{2} . \mathbf{S}_{2}\right) \\
& +\beta \mathbf{H}\left(\mathbf{L}_{1}+2 \mathbf{S}_{1}+\mathbf{L}_{2}+2 \mathbf{S}_{2}\right),
\end{aligned}
$$

where the first term describes ligand field effects, the second is the exchange coupling between the electrons, and the third and fourth contributions are the spin-orbit and Zeeman interactions. The crystal field effects lead to a mainly metal $d\left(x^{2}-y^{2}\right)$ ground state orbital with its lobes along the $\mathrm{Cu}-\mathrm{O}$ bonds, energetically well separated from the electronic excited states. The exchange interaction produces the largest (firstorder) perturbation to the spin fourfold-degenerated ground state by splitting it into diamagnetic singlet (total spin $S=0$ ) and paramagnetic triplet $(S=1)$ levels, energy separated in $|J|$. Perturbation theory up to second-order including exchange spin-orbit and Zeeman interactions shows that the triplet state can be described by the effective spin $(S=1)$ Hamiltonian

$$
H_{\mathrm{eff}}=\mathbf{S . D . S}+\beta \mathbf{S . g . H},
$$

where $\mathbf{D}$ and $\mathbf{g}$ are the fine and gyromagnetic tensors, respectively. The fine interaction splits the triplet state in the absence of an external magnetic field into a singlet and a doublet. It arises from the combined effect of ligand field, exchange and spin-orbit interactions and vanishes for uncoupled $(J=0)$ electrons. The symmetric $\mathbf{D}$ and $\mathbf{g}$ tensors share the same principal $(x, y, z)$ axes, where the spin Hamiltonian adopts the form

$$
H_{\mathrm{eff}}=D S_{z}^{2}+E\left(S_{x}^{2}-S_{y}^{2}\right)+\beta\left(g_{x} H_{x} S_{x}+g_{y} H_{y} S_{y}+g_{z} H_{z} S_{z}\right) .
$$

Single-crystal EPR measurements in the closely related system of $\mathrm{Cu}_{2}\left(\mathrm{CH}_{3} \mathrm{COO}\right)_{4}\left(\mathrm{H}_{2} \mathrm{O}\right)_{2}$ shows that the dimer exhibits approximate axial symmetry and therefore $E \simeq 0, g_{x} \simeq g_{y}$ $\simeq g_{\perp}$ and $g_{z}=g_{\|}$(Bleaney \& Bowers, 1952). Assuming the same holds for our system, (3) further simplifies to

$$
H_{\mathrm{eff}}=D S_{z}^{2}+\beta\left[g_{\perp}\left(H_{x} S_{x}+H_{y} S_{y}\right)+g_{||} H_{z} S_{z}\right] .
$$

The fine and Zeeman interactions (a fraction of $1 \mathrm{~cm}^{-1}$ ) are much smaller than the exchange interaction (in the present case, a few hundredths of $\mathrm{a} \mathrm{cm}^{-1}$ ). This interaction, in turn, is

\begin{tabular}{|c|c|c|c|c|}
\hline & $x$ & $y$ & $z$ & $U_{\text {eq }}$ \\
\hline $\mathrm{Cu}$ & 0.10395 (4) & 0.45719 (3) & 0.01842 (2) & $0.0564(2)$ \\
\hline O11 & $0.2103(2)$ & 0.6037 (2) & 0.0749 (2) & $0.0755(7)$ \\
\hline $\mathrm{O} 12$ & $0.0340(3)$ & $0.6753(2)$ & $0.0450(2)$ & $0.0738(7)$ \\
\hline $\mathrm{C} 11$ & 0.1594 (4) & $0.6801(3)$ & $0.0795(2)$ & $0.0635(9)$ \\
\hline $\mathrm{C} 12$ & $0.2546(5)$ & $0.7861(3)$ & $0.1286(3)$ & $0.0900(13)$ \\
\hline C13 & $0.3620(6)$ & $0.7753(4)$ & $0.2037(3)$ & $0.119(2)$ \\
\hline $\mathrm{C} 14$ & $0.3002(5)$ & $0.7241(4)$ & $0.2708(3)$ & $0.1032(15)$ \\
\hline C15 & $0.4061(8)$ & $0.7233(5)$ & $0.3483(4)$ & 0.149 (3) \\
\hline C16 & $0.3615(7)$ & $0.6762(5)$ & $0.4168(4)$ & $0.125(2)$ \\
\hline $\mathrm{C} 17$ & $0.4698(9)$ & $0.6783(6)$ & $0.4930(4)$ & $0.156(3)$ \\
\hline C18 & $0.4390(8)$ & $0.6327(6)$ & $0.5634(4)$ & $0.150(2)$ \\
\hline C19 & $0.5486(11)$ & $0.6364(7)$ & $0.6368(5)$ & 0.193 (4) \\
\hline $\mathrm{C} 110$ & $0.5294(12)$ & $0.5972(8)$ & $0.7081(6)$ & $0.243(5)$ \\
\hline $\mathrm{O} 21$ & $0.1358(2)$ & $0.5074(2)$ & $-0.08604(14)$ & $0.0690(6)$ \\
\hline $\mathrm{O} 22$ & -0.0400 & $0.5803(2)$ & $-0.1173(2)$ & $0.0776(7)$ \\
\hline $\mathrm{C} 21$ & $0.0622(4)$ & $0.5559(3)$ & -0.1319 & $0.0652(9)$ \\
\hline $\mathrm{C} 22$ & $0.1020(5)$ & $0.5869(5)$ & -0.2092 & 0.107 (2) \\
\hline $\mathrm{C} 23$ & -0.0062 (4) & $0.6012(4)$ & -0.2789 & $0.0834(12)$ \\
\hline $\mathrm{C} 24$ & 0.0357 (5) & $0.6294(4)$ & -0.3555 (2) & 0.0963 (14) \\
\hline $\mathrm{C} 25$ & $-0.0698(5)$ & $0.6432(5)$ & -0.4265 & $0.111(2)$ \\
\hline $\mathrm{C} 26$ & $-0.0331(6)$ & $0.6702(4)$ & -0.5030 & $0.1043(15)$ \\
\hline $\mathrm{C} 27$ & $-0.1412(7)$ & $0.6847(6)$ & -0.5740 & $0.136(2)$ \\
\hline $\mathrm{C} 28$ & $-0.1105(7)$ & $0.7088(5)$ & -0.6513 & $0.132(2)$ \\
\hline $\mathrm{C} 29$ & $-0.2204(9)$ & $0.7217(8)$ & -0.7215 & 0.195 (4) \\
\hline $\mathrm{C} 210$ & $-0.1972(10)$ & 0.7449 (7) & -0.7960 & $0.206(4)$ \\
\hline N3 & 0.2843 & 0.3929 (3) & $0.0471(2)$ & $0.0620(7)$ \\
\hline C31 & $0.2706(4)$ & $0.2926(3)$ & $0.0172(2)$ & $0.0650(9)$ \\
\hline C32 & $0.3890(4)$ & $0.2567(3)$ & $0.0207(2)$ & $0.0731(10)$ \\
\hline C33 & $0.5196(4)$ & $0.3283(4)$ & $0.0548(3)$ & 0.0857 (13) \\
\hline C34 & $0.5326(4)$ & $0.4298(4)$ & $0.0875(3)$ & 0.0880 \\
\hline $\mathrm{C} 35$ & $0.4130(4)$ & 0.4599 (4) & $0.0821(2)$ & 0.0749 (11) \\
\hline C36 & $0.3746(5)$ & $0.1470(4)$ & -0.0151 & $0.0896(13)$ \\
\hline O31 & $0.4702(4)$ & $0.1206(3)$ & -0.0311 & $0.1292(13)$ \\
\hline $\mathrm{O} 32$ & $0.2456(4)$ & $0.0796(2)$ & $-0.0285(2)$ & $0.0933(9)$ \\
\hline C37 & $0.2233(7)$ & -0.0308 & -0.0645 & $0.123(2)$ \\
\hline $\mathrm{C} 38$ & $0.0733(8)$ & -0.0924 & -0.0752 & $0.132(2)$ \\
\hline C39 & $-0.0347(7)$ & $-0.0551(5)$ & $-0.1366(4)$ & $0.128(2)$ \\
\hline C310 & $-0.0369(8)$ & $-0.0738(5)$ & $-0.2247(5)$ & $0.144(2)$ \\
\hline C311 & $-0.1377(7)$ & $-0.0354(6)$ & $-0.2844(5)$ & 0.149 (2) \\
\hline C312 & $-0.1397(8)$ & $-0.0449(6)$ & -0.3740 & $0.145(2)$ \\
\hline C313 & $-0.2330(8)$ & $0.0001(6)$ & -0.4301 & $0.157(3)$ \\
\hline C314 & $-0.2346(8)$ & $-0.0035(5)$ & -0.5189 & $0.144(2)$ \\
\hline C315 & $-0.3294(8)$ & $0.0446(6)$ & -0.5730 & $0.161(3)$ \\
\hline C316 & $-0.3324(8)$ & $0.0469(5)$ & $-0.6608(5)$ & 0.139 (2) \\
\hline C317 & $-0.4337(11)$ & $0.0948(8)$ & $-0.7127(6)$ & $0.201(4)$ \\
\hline C318 & $-0.4441(11)$ & $0.1012(7)$ & -0.7969 (6) & $0.198(4)$ \\
\hline
\end{tabular}
much less than the energy separation between electronic
Table 2

Fractional atomic coordinates and equivalent isotropic displacement parameters $\left(\AA^{2}\right)$.

ground and excited states. This warrants the description of the powder molar magnetic susceptibility by the Van Vleck expression, which to second-order approximation leads to the Bleaney-Bowers equation

$$
\chi(T)=\left[\frac{2 N g^{2} \beta^{2}}{k T\left(3+e^{-j / k T}\right)}+T I P\right](1-\rho)+\frac{N g_{p}^{2} \beta^{2}}{2 k T} \rho
$$

The TIP contribution to $\chi$ corresponds to temperature-independent paramagnetic effects and the last term in (5) accounts for the presence of small amounts of paramagnetic impurities in a proportion $\rho . g^{2}$ is an isotropic average of the squared $\mathbf{g}$ tensor, the $g_{p}$ value can be taken to be equal to 2 and the other parameters have their usual meaning. 
Table 3

Selected geometric parameters $\left(\AA,^{\circ}\right)$.

\begin{tabular}{llll}
\hline $\mathrm{Cu}-\mathrm{O} 12^{\mathrm{i}}$ & $1.950(3)$ & $\mathrm{O} 11-\mathrm{C} 11$ & $1.242(4)$ \\
$\mathrm{Cu}-\mathrm{O} 11$ & $1.960(3)$ & $\mathrm{O} 12-\mathrm{C} 11$ & $1.254(4)$ \\
$\mathrm{Cu}-\mathrm{O} 22^{\mathrm{i}}$ & $1.962(2)$ & $\mathrm{C} 11-\mathrm{C} 12$ & $1.504(5)$ \\
$\mathrm{Cu}-\mathrm{O} 21$ & $1.966(2)$ & $\mathrm{O} 21-\mathrm{C} 21$ & $1.252(4)$ \\
$\mathrm{Cu}-\mathrm{N} 3$ & $2.183(3)$ & $\mathrm{O} 22-\mathrm{C} 21$ & $1.247(4)$ \\
$\mathrm{Cu}-\mathrm{Cu}$ & $2.6146(10)$ & $\mathrm{C} 21-\mathrm{C} 22$ & $1.493(5)$ \\
& & & \\
$\mathrm{N} 3-\mathrm{C} 31$ & $1.323(4)$ & $\mathrm{C} 33-\mathrm{C} 34$ & $1.356(6)$ \\
$\mathrm{N} 3-\mathrm{C} 35$ & $1.329(4)$ & $\mathrm{C} 34-\mathrm{C} 35$ & $1.366(5)$ \\
$\mathrm{C} 31-\mathrm{C} 32$ & $1.401(5)$ & $\mathrm{C} 36-\mathrm{O} 31$ & $1.206(5)$ \\
$\mathrm{C} 32-\mathrm{C} 33$ & $1.362(6)$ & $\mathrm{C} 36-\mathrm{O} 32$ & $1.321(5)$ \\
$\mathrm{C} 32-\mathrm{C} 36$ & $1.466(6)$ & & \\
& & & \\
$\mathrm{O} 12^{\mathrm{i}}-\mathrm{Cu}-\mathrm{O} 22^{\mathrm{i}}$ & $90.31(12)$ & $\mathrm{O} 11-\mathrm{Cu}-\mathrm{Cu}$ & $82.90(8)$ \\
$\mathrm{O} 11-\mathrm{Cu}-\mathrm{O} 22^{\mathrm{i}}$ & $89.42(12)$ & $\mathrm{O} 22^{\mathrm{i}}-\mathrm{Cu}-\mathrm{Cu}$ & $85.18(7)$ \\
$\mathrm{O} 12^{\mathrm{i}}-\mathrm{Cu}-\mathrm{O} 21$ & $88.59(11)$ & $\mathrm{O} 21-\mathrm{Cu}-\mathrm{Cu}^{\mathrm{i}}$ & $83.16(7)$ \\
$\mathrm{O} 11-\mathrm{Cu}-\mathrm{O} 21$ & $89.27(11)$ & $\mathrm{N} 3-\mathrm{Cu}-\mathrm{Cu}$ & $177.08(8)$ \\
$\mathrm{O} 22^{\mathrm{i}}-\mathrm{Cu}-\mathrm{O} 21$ & $168.33(9)$ & $\mathrm{C} 11-\mathrm{O} 11-\mathrm{Cu}$ & $125.0(2)$ \\
$\mathrm{O} 12^{\mathrm{i}}-\mathrm{Cu}-\mathrm{N} 3$ & $96.76(11)$ & $\mathrm{C} 11-\mathrm{O} 12-\mathrm{Cu}$ & $122.5(2)$ \\
$\mathrm{O} 11-\mathrm{Cu}-\mathrm{N} 3$ & $95.15(11)$ & $\mathrm{O} 11-\mathrm{C} 11-\mathrm{O} 12$ & $124.4(3)$ \\
$\mathrm{O} 22^{\mathrm{i}}-\mathrm{Cu}-\mathrm{N} 3$ & $97.00(10)$ & $\mathrm{O} 11-\mathrm{C} 11-\mathrm{C} 12$ & $118.1(3)$ \\
$\mathrm{O} 21-\mathrm{Cu}-\mathrm{N} 3$ & $94.66(10)$ & $\mathrm{O} 12-\mathrm{C} 11-\mathrm{C} 12$ & $117.5(3)$ \\
$\mathrm{O} 12^{\mathrm{i}}-\mathrm{Cu}-\mathrm{Cu}$ & $85.15(8)$ & $\mathrm{C} 21-\mathrm{O} 21-\mathrm{Cu}$ & $124.4(2)$ \\
& & & \\
$\mathrm{C} 21-\mathrm{O} 22-\mathrm{Cu}$ & \\
$\mathrm{O} 22-\mathrm{C} 21-\mathrm{O} 21$ & $122.3(2)$ & $\mathrm{C} 31-\mathrm{C} 32-\mathrm{C} 36$ & $121.4(4)$ \\
$\mathrm{O} 22-\mathrm{C} 21-\mathrm{C} 22$ & $124.9(3)$ & $\mathrm{C} 34-\mathrm{C} 33-\mathrm{C} 32$ & $120.0(3)$ \\
$\mathrm{O} 21-\mathrm{C} 21-\mathrm{C} 22$ & $118.4(3)$ & $\mathrm{C} 33-\mathrm{C} 34-\mathrm{C} 35$ & $118.7(4)$ \\
$\mathrm{C} 31-\mathrm{N} 3-\mathrm{C} 35$ & $119.7(3)$ & $\mathrm{N} 3-\mathrm{C} 35-\mathrm{C} 34$ & $122.6(4)$ \\
$\mathrm{C} 31-\mathrm{N} 3-\mathrm{Cu}$ & $120.2(2)$ & $\mathrm{O} 31-\mathrm{C} 36-\mathrm{O} 32$ & $123.2(5)$ \\
$\mathrm{C} 35-\mathrm{N} 3-\mathrm{Cu}$ & $119.7(3)$ & $\mathrm{O} 31-\mathrm{C} 36-\mathrm{C} 32$ & $123.7(5)$ \\
$\mathrm{N} 3-\mathrm{C} 31-\mathrm{C} 32$ & $121.2(4)$ & $\mathrm{C} 36-\mathrm{O} 32-\mathrm{C} 32$ & $113.1(4)$ \\
$\mathrm{C} 33-\mathrm{C} 32-\mathrm{C} 31$ & $118.3(4)$ & $\mathrm{O} 32-\mathrm{C} 37-\mathrm{C} 38$ & $116.1(4)$ \\
$\mathrm{C} 33-\mathrm{C} 32-\mathrm{C} 36$ & $120.2(4)$ & & $107.7(4)$ \\
\hline & & & \\
\hline
\end{tabular}

Symmetry code: (i) $-x, 1-y,-z$.

Least-squares fit of (5) to the susceptibility data leads to the following parameters: $-J=347(1) \mathrm{cm}^{-1}, g=2.037$ (4) and $\rho=$ 0.65 (1) \%; the value of the TIP is not meaningful because of uncertainties in the diamagnetic correction of such a large molecule. The corresponding $\chi(T)$ curve is compared in Fig. 3 with the experimental susceptibility.

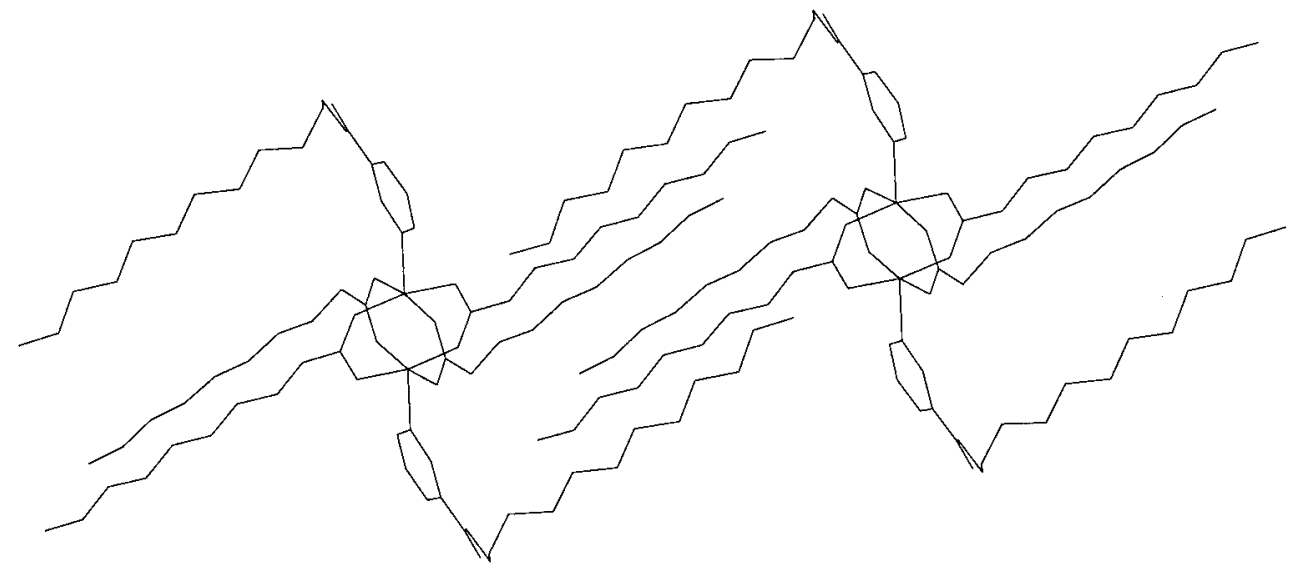

Figure 2

ORTEP (Johnson, 1965) drawing showing two dimeric units of $\mathrm{Cu}_{2}\left(\mathrm{O}_{2} \mathrm{CC}_{9} \mathrm{H}_{19}\right)_{4}\left(\mathrm{C}_{5} \mathrm{H}_{4} \mathrm{NCOOC}_{12} \mathrm{H}_{25}\right)_{2}$ symmetry related by a unit-cell translation along $\mathbf{c}$.
Table 4

Transition temperature $(\mathrm{K})$ and enthalpy (in $\mathrm{kJ} \mathrm{mol}^{-1}$ within parentheses) for $\mathrm{Cu}_{2}\left(\mathrm{O}_{2} \mathrm{CC}_{n-1} \mathrm{H}_{2 n-1}\right)_{4}\left(\mathrm{C}_{5} \mathrm{H}_{4} \mathrm{NCOOC}_{12} \mathrm{H}_{25}\right)_{2}$ derivatives.

$C_{1}, C_{2}, C_{3}$ refer to crystalline phases; $I$ refers to the isotropic phase.

\begin{tabular}{lll}
\hline$n=10$ & $C \rightarrow I$ & $315(97)$ \\
$n=12$ & $C_{1} \rightarrow C_{2}$ & $318(<2)$ \\
& $C_{2} \rightarrow I$ & $328(90)$ \\
$n=14$ & $C_{1} \rightarrow C_{2}$ & $316(3)$ \\
& $C_{2} \rightarrow I$ & $334(162)$ \\
$n=16$ & $C_{1} \rightarrow C_{2}$ & $310(14)$ \\
& $C_{2} \rightarrow C_{3}$ & $337(153)$ \\
& $C_{3} \rightarrow I$ & $364(29)$ \\
$n=18$ & $C_{1} \rightarrow C_{2}$ & $333(73)$ \\
& $C_{2} \rightarrow I$ & $370(70)$ \\
$n=20$ & $C_{1} \rightarrow C_{2}$ & $325(13)$ \\
& $C_{2} \rightarrow C_{3}$ & $339(121)$ \\
& $C_{3} \rightarrow I$ & $377(32)$ \\
\hline
\end{tabular}

The compound shows a strong intramolecular antiferromagnetic interaction, which can be attributed to $\mathrm{Cu}-\mathrm{Cu}$ superexchange through the carboxylate groups. In order to correlate these magnetic results with structural characteristics, we verified that the diffraction pattern of the bulk powdered sample used for magnetic experiments effectively agrees with that calculated from the crystallographic data. In general, the values of the magnetic parameters agree with those already published for $\mathrm{Cu}_{2}\left(\mathrm{O}_{2} \mathrm{C}_{n} \mathrm{H}_{2 n-1}\right)_{4} L_{2}$ compounds, where $L$ coordinates via $\mathrm{N}$ atoms. The more relevant parameter, $|J|$, is near the upper limit of the thus far reported values (308-353 $\mathrm{cm}^{-1}$; Kato \& Muto, 1988; Kawata et al., 1992; Melník et al., 1985), which seems in agreement with the short $\mathrm{Cu}-\mathrm{O}$ bond distances. The correlation of $|J|$ with the basicity of the ligand has been the subject of some controversy in the literature. Indeed, some authors invoked an increase of the exchange parameter as the axial ligand becomes a stronger electron donor (Melník et al., 1985; Melník, 1982); contrarily, others claimed (Kato \& Muto, 1988) that the AF superexchange increases as the axial ligand basicity decreases, a fact that has been interpreted as a consequence of the strong $\mathrm{Cu}-$ $\mathrm{O}$ bonds (shorter distances) present in order to maintain the local electroneutrality of copper(II) ions, which enhance the overlap between magnetic orbitals through the bridge's HOMO, resulting in a stronger AF interaction. Our results seem to support the conclusion drawn by Kato and Muto. However, the magnetic coupling described by $J$ depends simultaneously on several factors and it cannot be assigned only to the ligand basicity. For example, it has been found that there is no correlation between $J$ and the $\mathrm{Cu}-\mathrm{Cu}$ distance (as expected for a bridged-mediated coupling 
mechanism; Melník, 1982), but a marked one with the bend angle defined by the $\mathrm{O}-\mathrm{Cu}-\mathrm{Cu}-\mathrm{O}$ and $\mathrm{O}-\mathrm{C}-\mathrm{O}$ planes (Kawata et al., 1992): the smaller the bend angle, the stronger the superexchange coupling through the carboxylates, due to a good overlap between magnetic orbitals in the $\mathrm{Cu}-\mathrm{O}-\mathrm{C}-$ $\mathrm{O}-\mathrm{Cu}$ fragment. In the present compound the very small bend angle $\left(0.8^{\circ}\right)$ agrees with the high $|J|$ value.

\section{Conclusions}

The use of long-chain nicotinate derivatives as axial ligands was successful in order to break out the polymeric structure of dicopper carboxylates.

Even if they did not present liquid crystal phases, there is evidence in the crystal structure of the decylcarboxylate adduct of a microsegregation of the alkyl chains from the remaining, and more polar, part of the molecule. In fact, the compounds with the longest alkyl chains exhibit a lamellar crystalline structure whose interlamellar distance was related to the largest dimension of one molecule. Those results indicate that this system could be slightly modified to induce the appearance of liquid crystal smectic phases.

The structural analysis of the decyl derivative allowed the interpretation of the magnetic behavior of this compound, which exhibits one of the strongest antiferromagnetic interactions among this type of dinuclear copper compounds. The short $\mathrm{Cu}-\mathrm{O}$ distance, in addition to the coplanarity of the $\mathrm{Cu}-\mathrm{O}-\mathrm{C}-\mathrm{O}-\mathrm{Cu}$ group, warrant a large overlap between the $d_{x^{2}-y^{2}}$ magnetic orbital of the $\mathrm{Cu}^{2+}$ cation and the lone pair of the $\mathrm{O}$ atom that leads to a strong superexchange interaction between the metallic atoms through the carboxylate's bridge.

We wish to warmly thank Richard Poinsot (GMI, IPCMS, Strasbourg) for his valuable and kind assistance in magnetic

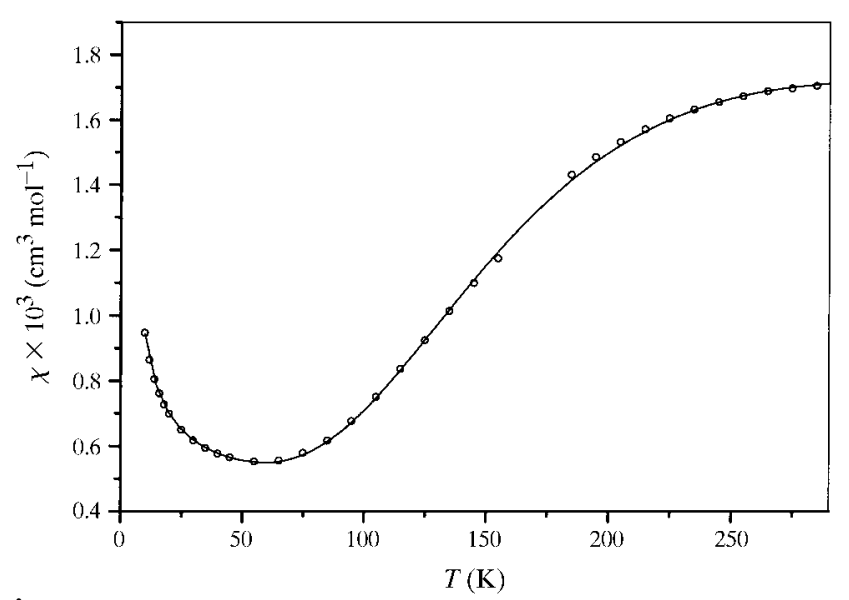

Figure 3

Temperature dependence of the measured molar magnetic susceptibility $\chi(\mathrm{O})$ for the complex $\mathrm{Cu}_{2}\left(\mathrm{O}_{2} \mathrm{CC}_{9} \mathrm{H}_{19}\right)_{4}\left(\mathrm{C}_{5} \mathrm{H}_{4} \mathrm{NCOOC}_{12} \mathrm{H}_{25}\right)_{2}$. The solid line corresponds to the value calculated with the model described in the text. measurements, Benoît Heinrich (GMO, Strasbourg) for his help and advice on the variable-temperature XRD experiments as well as Elsa Sileo and Matías Jobbágy (INQUIMAE) for their acquisition and simulation of some of the XRD patterns. Single-crystal X-ray experiments were carried out at the National Diffraction Laboratory (LANADI), La Plata, Argentina. Elemental analyses and room-temperature powder X-ray diffraction determinations were performed at INQUIMAE, Buenos Aires, Argentina. Variable-temperature powder X-ray diffraction data were collected at the Groupe des Matériaux Organiques and magnetic susceptibility data at Groupe des Matériaux Inorganiques (IPCMS, Strasbourg, France). This work was supported by CONICET, Fundación Antorchas, ANPCyT and CICPBA of Argentina and by a Secyt-Ecos grant (A97E08) for international cooperation. CONICET is also acknowledged for research fellowships to ZC and MR. FDC and OEP are members of CONICET.

\section{References}

Abied, H., Guillon, D., Skoulios, A., Weber, P., Giroud-Godquin, A. M. \& Marchon, J. C. (1987). Liq. Cryst. 2, 269-279.

B. A. Frenz \& Associates (1983). Enraf-Nonius Structure Determination Package. Enraf-Nonius, Delft, The Netherlands.

Bleaney, B. \& Bowers, K. D. (1952). Proc. R. Soc. London Sect. A, 214, 451-465.

Busing, W. R. \& Levy, H. A. (1957). Acta Cryst. 10, 180-182.

Deacon, G. B. \& Phillips, R. J. (1980). Coord. Chem. Rev. 33, 227-250.

Ibn-Elhaj, M., Guillon, D., Skoulios, A., Giroud-Godquin, A. M. \& Maldivi, P. (1992). Liq. Cryst. 11, 731-744.

Johnson, C. K. (1965). ORTEP. Report ORNL-3794. Oak Ridge National Laboratory, Tennessee, USA.

Kahn, O. (1993). Molecular Magnetism, pp. 103-120. Weinheim: VCH Publishers, Inc.

Kato, M. \& Muto, Y. (1988). Coord. Chem. Rev. 92, 45-83.

Kawata, T., Uekusa, H., Ohba, S., Furukawa, T., Tokii, T., Muto, Y. \& Kato, V. (1992). Acta Cryst. B48, 253-261.

Kozlevcar, B., Fajfar, S., Petric, M., Pohleven, F. \& Segedin, P. (1996). Acta Chim. Slov. 43, 385-395.

Marchon, J. C., Maldivi, P., Giroud-Godquin, A. M., Guillon, D., IbnElhaj, M. \& Skoulios, A. (1992). Nanostructures Based on Molecular Materials, edited by W. Göpel and C. Ziegler, pp. 285291. Weinheim: VCH Publishers, Inc.

Mehrotra, R. C. \& Bohra, R. (1983). Metal Carboxylates. London: Academic Press.

Melník, M. (1982). Coord. Chem. Rev. 42, 259-293.

Melník, M., Smolander, K. \& Sharrock, P. (1985). Inorg. Chim. Acta, 103, 187-194.

Pauling, L. (1960). The Nature of the Chemical Bond, 3rd ed., p. 172. Ithaca: Cornell University Press.

Reilley, C. N. \& Sawyer, D. T. (1961). Experiments for Instrumental Methods, p. 176. New York: McGraw-Hill.

Selwood, G. M. (1956). Magnetochemistry, 2nd ed., p. 78. New York: Interscience.

Sheldrick, G. M. (1990). Acta Cryst. A46, 467-473.

Sheldrick, G. M. (1993). SHELXL93. University of Göttingen, Germany. 